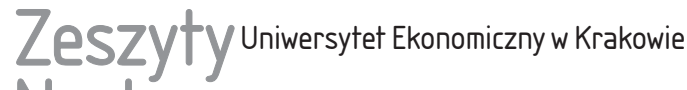 Naukowe
}

1(961)

ISSN 1898-6447

Zesz. Nauk. UEK, 2017; 1 (961): 39-52

DOI: 10.15678/ZNUEK.2017.0961.0103

Sylwia Stupik

\section{Usługi publiczne w polityce zrównoważonego rozwoju gmin - wybrane problemy}

\section{Streszczenie}

Celem opracowania jest identyfikacja podstawowych barier i korzyści zrównoważonego rozwoju gmin z punktu widzenia władz oraz wskazanie głównych kierunków i obszarów działań władzy publicznej w zakresie technicznych i środowiskowych usług publicznych. W artykule omówiono wyniki badań empirycznych przeprowadzonych w 2015 r. wśród gmin województwa wielkopolskiego, śląskiego i podlaskiego. Podstawowym wnioskiem, jaki nasuwa się po przeprowadzonej analizie, jest stwierdzenie, że skuteczna realizacja polityki opartej na zasadach zrównoważonego rozwoju zależy w dużej mierze od świadomości i zaangażowania władz lokalnych. W wielu gminach nie ma równowagi między ładem gospodarczym, społecznym i środowiskowym, a działania mające na celu poprawę jakości życia mieszkańców i programowanie zrównoważonego rozwoju często pozostają w sferze deklaracji.

Słowa kluczowe: zrównoważony rozwój, usługi publiczne, gminy, Polska.

Klasyfikacja JEL: Q53, Q56, Q58.

\section{Wprowadzenie}

Proces rozwoju polega w głównej mierze na poprawie istniejących lub tworzeniu nowych walorów użytkowych jednostki terytorialnej, możliwości rozwoju gospodarki i wzrostu korzyści zewnętrznych dla podmiotów gospodar-

Sylwia Słupik, Uniwersytet Ekonomiczny w Katowicach, Wydział Ekonomii, Katedra Polityki Społecznej i Gospodarczej, ul. 1 Maja 50,40-287 Katowice, e-mail: sylwia.slupik@ue.katowice.pl 
czych oraz walorów lokalnego i regionalnego ekosystemu i ładu przestrzennego. Zrównoważony rozwój traktuje gospodarkę, środowisko i społeczeństwo jako zintegrowany kompleks [Fiedor i Jończy 2009, s. 41-42], w którym nadrzędny cel poprawy jakości życia będzie realizowany dzięki zróżnicowanym działaniom na szczeblu lokalnym i regionalnym z zachowaniem właściwych proporcji w wymiarze gospodarczym, środowiskowo-przestrzennym i społecznym, w tym instytucjonalno-politycznym [Borys 2011]. Jednocześnie zrównoważony rozwój jest zjawiskiem długotrwałym i złożonym, które obejmuje kwestie społeczno-gospodarcze, zrównoważoną konsumpcję i produkcję, włączenie społeczne, zmiany demograficzne, zdrowie publiczne, zmiany klimatu i gospodarowanie energią, zrównoważony transport, zasoby naturalne, dobre rządzenie i globalne partnerstwo. W dobie wzrostu udziału sektora usług jako dominującego rodzaju działalności gospodarczej zwiększa się również rozmiar oraz różnorodność usług o charakterze ogólnodostępnym i zarazem odgrywających szczególną rolę w funkcjonowaniu społeczeństwa danego państwa jako całości. Stąd realizacja usług publicznych jest uznawana za jeden z głównych powodów powoływania samorządu lokalnego, rozumianego jako wspólnota mieszkańców na danym obszarze, a nie tylko jako władza lokalna. Usługi publiczne w znacznym stopniu wpływają na jakość życia mieszkańców i na warunki inwestowania, a w efekcie na rozwój gospodarczy. Ponadto są one jednym z kluczowych czynników, od których zależy rozwój lokalny, przyczyniając się do wzrostu satysfakcji jego obywateli.

W literaturze przedmiotu znaleźć można różne poglądy na temat usług publicznych oraz ich liczne klasyfikacje (np. [Stiglitz 2004, Flejtarski i in. 2012, Kożuch i Kożuch 2011, Szarfenberg 2009]). We wszystkich ujęciach definicyjnych podkreśla się, że usługi publiczne należy traktować jako dobra materialne i niematerialne, świadczone w szeroko pojętym interesie publicznym. Odpowiedzialność za zapewnienie dostępu do nich i odpowiedni ich poziom spoczywa na władzy publicznej. Ponadto niemożliwe jest wykluczenie kogokolwiek z korzystania z nich. Usługi publiczne mogą być świadczone przez administrację publiczną bezpośrednio ludności w ramach sektora publicznego lub przez podmioty prywatne zapewniające daną usługę. Samorząd terytorialny powinien jednak tworzyć warunki do zwiększenia udziału sektora prywatnego i pozarządowego w dostarczaniu usług publicznych, a jednocześnie zwiększać własną aktywność w monitorowaniu poziomu dostępności i efektywności świadczenia tychże usług.

Podstawowy katalog usług publicznych zaproponował W. Wańkowicz. Podzielił je na trzy kategorie [2004, s. 8]:

1) usługi o charakterze administracyjnym, związane bezpośrednio z realizacją czynności administracyjnych, w tym z wydawaniem decyzji administracyjnych. Tego typu usługi realizowane są w urzędach administracji samorządowej pełniących równocześnie funkcję organizatora i realizatora usług. Standardy realizacji 
tego rodzaju usług związane są przede wszystkim z poziomem kultury obsługi klientów w danym urzędzie oraz wiedzą i kompetencjami pracowników samorządowych;

2) usługi o charakterze społecznym, ukierunkowane na rozwój społeczeństwa i zaspokojenie potrzeb społecznych, takich jak: edukacja, kultura, ochrona zdrowia, pomoc społeczna itp., wykonywane są zwykle przez samorządowe jednostki organizacyjne lub jednostki posiadające osobowość prawną, dla których organem założycielskim jest jednostka samorządu terytorialnego. Głównym wyzwaniem dla tej kategorii usług jest racjonalność ekonomiczna oraz utrzymanie właściwego standardu świadczonych usług, zwłaszcza w przypadku kiedy jest on wyznaczany odrębnymi regulacjami prawnymi;

3) usługi o charakterze technicznym (komunalne), związane z realizacją zadań publicznych w takich obszarach, jak: dostarczanie wody, odprowadzanie i oczyszczanie ścieków, dostarczanie energii cieplnej, elektrycznej i gazu, zagospodarowanie i składowanie odpadów, usługi komunikacyjne, utrzymanie i modernizacja dróg. Świadczenie tego typu usług może odbywać się za pośrednictwem jednostek podległych samorządowi, spółek o kapitale mieszanym lub też przedsiębiorstw prywatnych.

Usługi publiczne, w tym głównie ich dostępność i jakość (szczególnie tych społecznych i technicznych), przekładają się bezpośrednio na jakość życia społeczności lokalnej. Aspekty te wpływają także na kształtowanie i ocenę polityki rozwoju, usługi publiczne mogą być bowiem czynnikiem, ale też barierą procesów rozwojowych. Jak pokazują badania empiryczne, różnice w rozwoju regionalnym w tych sferach są wciąż bardzo duże. Stąd też województwa silnie rozwinięte pod względem gospodarczym i społecznym powinny zwiększać inwestycje w ochronę środowiska przyrodniczego, natomiast regiony o wysokiej jakości środowiska powinny wykorzystać swój potencjał endogeniczny do zdynamizowania rozwoju gospodarczego i powiększenia kapitału ludzkiego w ramach tzw. zielonej gospodarki, kreując innowacje środowiskowe, inwestując w branże wspierające ochronę środowiska i tworzące tzw. zielone miejsca pracy [Perło 2013, s. 207].

Celem niniejszego opracowania jest wskazanie głównych kierunków i obszarów działań władzy publicznej w zakresie technicznych i środowiskowych usług publicznych oraz identyfikacja podstawowych barier i korzyści zrównoważonego rozwoju gmin z punktu widzenia władz. Ponadto w artykule starano się zaprezentować podstawowe źródła finansowania realizowanych w gminach przedsięwzięć inwestycyjnych z zakresu analizowanych usług publicznych. W artykule zostaną omówione wyniki badań empirycznych pracowników Katedry Polityki Społecznej i Gospodarczej Uniwersytetu Ekonomicznego w Katowicach przeprowadzonych w 2015 r., a dotyczących polityki zrównoważonego rozwoju na szczeblu krajowym, regionalnym i lokalnym. Badania ankietowe przeprowadzone 
zostały wśród przedstawicieli gmin województwa śląskiego, podlaskiego oraz wielkopolskiego. Ankiety zostały skierowane do wszystkich gmin wymienionych województw, ogółem uzyskano zwrot 261 ankiet (50,2\%). Najwyższy zwrot ankiet uzyskano z województwa śląskiego - $65 \%$ ogółu gmin województwa, następnie z województwa wielkopolskiego - 48\%, i podlaskiego - 38\%. Obszar badań został starannie wybrany z uwagi na zróżnicowanie województw pod względem uwarunkowań środowiskowo-przyrodniczych i zasobowych, charakteru i funkcji regionów, a także wyposażenia analizowanych województw w infrastrukturę techniczną i społeczną. Wszystkie te czynniki istotnie wpływają na sposoby i kierunki prowadzenia polityki lokalnej, a położenie geograficzne województw reprezentujących Polskę wschodnią, zachodnią i południową czyni badania reprezentatywnymi.

\section{Główne kierunki polityki zrównoważonego rozwoju w badanych gminach}

Transformacja systemowa, konstytuując zasadnicze zmiany w układach zależności, wprowadzając zasadę decentralizacji, pomocniczości i dialogu społecznego. zmieniła zakres obowiązków i funkcji pełnionych przez władze samorządowe. Konsekwencją tego jest rozszerzenie zadań publicznych samorządów terytorialnych, a przede wszystkim gmin, które stały się ważnymi podmiotami zarządzania gospodarką lokalną. W wielu dziedzinach rynek jako mechanizm alokacji zasobów okazuje się ułomny i dlatego pojawia się konieczność stymulowania rozwoju przez władze samorządowe. Polityka rozwojowa jest procesem złożonym i długofalowym, uwarunkowanym wieloma czynnikami, na które podmiot polityki ma ograniczone możliwości oddziaływania. Stąd też lokalna gospodarka musi być analizowana, rozumiana i wspierana w sposób uwzględniający specyficzne miejscowe warunki. Rozwój gospodarczy na szczeblu lokalnym oznacza przyrost środków i możliwości, które pozwalają lokalnej władzy i mieszkańcom lepiej zaspokajać większą liczbę potrzeb na wyższym poziomie. Nie jest on jednak wolny od zagrożeń. Może spowodować wzrost zanieczyszczeń albo zmienić sposób życia, który dotychczas był ceniony przez mieszkańców. Może też wpłynąć ujemnie na dotychczasowe obszary gospodarowania. Ponadto gminy nie rozwijają się równomiernie. Powodem może być niejednakowa dostępność do czynników produkcji bądź różna ich jakość. Poza tym istotne znaczenie ma także potencjał tkwiący w ludziach, ich aktywność, przedsiębiorczość i kreatywność. Stąd działania administracji publicznej w zakresie rozwoju gospodarczego powinny skupiać się na rozwiązywaniu problemów oraz wykorzystywaniu możliwości. 
Prowadzenie skutecznej zrównoważonej polityki lokalnej wymaga zatem od władz publicznych identyfikacji podstawowych potrzeb i problemów, które występują w środowisku gminnym. W przeprowadzonych badaniach respondenci wskazali podstawowe problemy środowiskowe występujące na terenie gminy i określali stopień ich natężenia (zob. tabela 1). Badane województwa i znajdujące się na ich terenie gminy zasadniczo różnią się między sobą pod względem uwarunkowań środowiskowo-przyrodniczych i zasobowych.

Województwo wielkopolskie charakteryzuje się dużym potencjałem przyrodniczym i możliwościami rozwoju sektora turystyki wiejskiej i agroturystyki. Pomimo złego stanu infrastruktury komunikacyjnej na peryferiach i zróżnicowanego poziomu rozwoju w poszczególnych subregionach województwo jest jednym z najlepiej rozwiniętych gospodarczo województw w Polsce. Charakteryzuje się wysoką koncentracją zaangażowanego kapitału zagranicznego w regionie oraz wysokimi nakładami inwestycyjnymi na jednego mieszkańca. To jednak region przede wszystkim rolniczy o klimacie stepowym, powodującym przy braku występowania opadów deficyt wód gruntowych. Województwo to posiada zróżnicowane predyspozycje do wykorzystania odnawialnych źródeł energii, szczególnie energetyki wiatrowej [Wielkopolska... 2012].

Województwo śląskie jest obszarem o silnej presji antropogenicznej, tj. silnie zurbanizowanym i uprzemysłowionym. Do głównych problemów środowiskowych regionu należy zaliczyć: złą jakość powietrza, niedostateczną jakość wód powierzchniowych i podziemnych, zanieczyszczenie gleb, uciążliwość hałasu komunikacyjnego oraz nieuporządkowanie gospodarki odpadami. Ponadto ze względu na istniejące uwarunkowania zasobowe region śląski jest historycznie związany z górnictwem węgla kamiennego i rozwojem innych rodzajów przemysłu ciężkiego. Rozwój przemysłu oraz jego późniejsza restrukturyzacja na terenie województwa przyczyniły się do powstania znacznej ilości terenów poprzemysłowych, których rewitalizacja jest jednym z najtrudniejszych problemów zarówno środowiskowych, jak i ekonomicznych regionu [Strategia rozwoju województwa ślaskiego... 2013]. Wreszcie województwo podlaskie, kojarzone z czystym środowiskiem, jest obszarem z dużym udziałem terenów cennych przyrodniczo. W województwie współwystępuje wysoka bioróżnorodność z bardzo niską emisją zanieczyszczeń, co daje możliwość świadczenia usług ekologicznych, w tym pozaprodukcyjnych, oraz rozwoju rolnictwa ekologicznego. Mankamentem regionu jest nieefektywna i przestarzała gospodarka odpadami oraz nieprawidłowa gospodarka ściekowa [Strategia rozwoju województwa podlaskiego... 2013].

Jak wynika z badań, wspólne obszary newralgiczne dla wszystkich badanych województw obejmowały przede wszystkim ochronę powietrza (ponad 54\% respondentów wskazało na częste występowanie problemu niskiej emisji na terenie gminy), gospodarkę odpadami (prawie $86 \%$ przedstawicieli gmin wskazało 
Tabela 1. Natężenie problemów ekologiczno-środowiskowych występujących w badanych gminach według wskazań respondentów (\% ważnych odpowiedzi)

\begin{tabular}{|c|c|c|c|}
\hline Opis problemu & $\begin{array}{l}\text { Problem } \\
\text { często } \\
\text { występuje }\end{array}$ & $\begin{array}{c}\text { Natężenie } \\
\text { problemu jest } \\
\text { niezbyt duże } \\
\text { lub problem } \\
\text { pojawia się } \\
\text { sporadycznie }\end{array}$ & $\begin{array}{c}\text { Nie zaobser- } \\
\text { wowano tego } \\
\text { problemu }\end{array}$ \\
\hline $\begin{array}{l}\text { Zakłady przemysłowe emitujące zanieczyszcze- } \\
\text { nia do powietrza }\end{array}$ & 10,9 & 38,1 & 51,0 \\
\hline Niska emisja z domów mieszkalnych & 54,2 & 32,4 & 13,4 \\
\hline $\begin{array}{l}\text { Zanieczyszczenia wynikające z dużego natęże- } \\
\text { nia ruchu samochodów }\end{array}$ & 25,2 & 50,0 & 24,8 \\
\hline Zanieczyszczenia wód przez ścieki komunalne & 16,7 & 49,8 & 33,5 \\
\hline Zanieczyszczenia wód przez ścieki przemysłowe & 3,5 & 26,8 & 69,6 \\
\hline Odpady przemysłowe & 5,8 & 24,5 & 69,6 \\
\hline $\begin{array}{l}\text { Zaśmiecanie i dzikie wysypiska odpadów komu- } \\
\text { nalnych }\end{array}$ & 21,6 & 64,1 & 14,3 \\
\hline Nadmierny hałas & 8,6 & 48,4 & 43,0 \\
\hline Szkody górnicze & 8,3 & 11,9 & 79,8 \\
\hline Zła jakość wody pitnej & 2,7 & 23,5 & 73,7 \\
\hline Zanieczyszczenie i degradacja gleb & 1,6 & 28,3 & 70,1 \\
\hline $\begin{array}{l}\text { Nadmierna wycinka drzew, likwidacja terenów } \\
\text { zielonych w mieście }\end{array}$ & 3,1 & 25,8 & 71,1 \\
\hline Zbyt intensywny wyrąb lasu & 0,8 & 11,1 & 88,1 \\
\hline Zbyt intensywny odłów zwierzyny & 0,4 & 6,3 & 93,3 \\
\hline Kłusownictwo & 0,4 & 12,9 & 86,7 \\
\hline $\begin{array}{l}\text { Dewastacja przyrody przez człowieka (np. nisz- } \\
\text { czenie, quady i motory na terenach leśnych) }\end{array}$ & 4,3 & 42,7 & 53 \\
\hline $\begin{array}{l}\text { Zajmowanie terenów zielonych przez budownic- } \\
\text { two (intensywne procesy urbanizacyjne) }\end{array}$ & 5,4 & 26,8 & 67,7 \\
\hline Nadmierne użytkowanie turystyczne & 1,6 & 11,3 & 87,1 \\
\hline Nadmierna intensyfikacja i chemizacja rolnictwa & 2,4 & 33,7 & 63,9 \\
\hline $\begin{array}{l}\text { Ograniczenia inwestycyjne spowodowane dużą } \\
\text { ilością chronionych obszarów }\end{array}$ & 3,2 & 21,7 & 75,1 \\
\hline
\end{tabular}

Uwaga: kolorem szarym zaznaczono pola z najwyższym udziałem procentowym wśród wszystkich ważnych odpowiedzi.

Źródło: opracowanie własne na podstawie wyników badań ankietowych. 
na problem zaśmiecania i występowania dzikich wysypisk odpadów komunalnych jako występujący często lub sporadycznie), transport, co wynika z dużego natężenia ruchu samochodów będącego źródłem zanieczyszczeń (problem pojawia się sporadycznie na terenie połowy badanych gmin, a często w jednej czwartej gmin). Ponadto sporadycznie występują zanieczyszczenia wód ściekami komunalnymi oraz nadmierny hałas (odpowiednio 49,8\% i 48,4\% wskazań). Wśród dziesięciu najrzadziej występujących problemów środowiskowych w badanych gminach (w kolejności od niemal w ogóle niewystępujących) znalazły się:

1) zbyt intensywny odłów zwierzyny;

2) zbyt intensywny wyrąb lasu;

3) nadmierne użytkowanie turystyczne - nawet gminy województwa podlaskiego jako potencjalnie jednego z najbardziej atrakcyjnych turystycznie regionu nie obserwują występowania tego zjawiska na swoim terenie (ponad 90\% gmin województwa zaznaczyło w ankiecie taką opcję). Walory przyrodnicze i kulturowe regionu nie idą w parze z obłożeniem turystycznym na Podlasiu, czego przyczyną może być brak spójnej koncepcji rozwoju turystyki;

4) kłusownictwo;

5) szkody górnicze - w gminach województwa śląskiego jako najbardziej narażonych na ich występowanie zauważa się pojawienie się szkód jako częstego problemu (16,7\% wskazań) bądź pojawiającego się sporadycznie (15,7\%), ale aż $67,7 \%$ gmin tego województwa nie deklaruje pojawienia się tego typu trudności. Dla pozostałych dwóch badanych województw występowanie szkód górniczych pozostaje kwestią marginalną;

6) ograniczenia inwestycyjne spowodowane dużą ilością chronionych obszarów;

7) zła jakość wody pitnej;

8) nadmierna wycinka drzew, likwidacja terenów zielonych w mieście;

9) zanieczyszczenie i degradacja gleb - mimo że ekspansja przestrzeni rolniczej na obszarze województwa wielkopolskiego przyczyniła się do nieodwracalnych zmian w stosunkach wodnych oraz zmieniła chemizm atmosfery, wód powierzchniowych, podziemnych oraz gruntu, $75 \%$ gmin województwa nie obserwuje problemu zanieczyszczenia gleb. Równocześnie ponad 40\% gmin Wielkopolski deklaruje nadmierną intensyfikację i chemizację rolnictwa jako kwestię sporadycznie występującą na ich terenie;

10) odpady przemysłowe i zanieczyszczenia wód przez ścieki przemysłowe.

Wskazane przez władze publiczne obszary problemowe pokrywają się $\mathrm{z}$ poziomem zaawansowania prowadzonych $\mathrm{w}$ ramach polityki gminnej działań (tabela 2) oraz priorytetami rozwoju gminy. W ankiecie uwzględniono wszystkie najważniejsze obszary działalności związane z sektorem usług publicznych o charakterze technicznym i środowiskowym, począwszy od szeroko rozumianej 
gospodarki wodno-ściekowej, gospodarki odpadami i transportu, przez gospodarkę związaną z efektywnością energetyczną, budownictwem ekologicznym i inwestycjami w odnawialne źródła energii, aż do działań związanych z ochroną przyrody i bioróżnorodności, utrzymania terenów zielonych i edukacji ekologicznej.

Tabela 2. Poziom zaawansowania działań w badanych gminach (\% ważnych odpowiedzi)

\begin{tabular}{|c|c|c|c|c|c|}
\hline \multirow[b]{2}{*}{ Rodzaj/obszar usług } & \multicolumn{5}{|c|}{ Poziom zaawansowania działań } \\
\hline & $\begin{array}{l}\text { bardzo } \\
\text { zaawan- } \\
\text { sowane }\end{array}$ & $\begin{array}{c}\text { średnio } \\
\text { zaawan- } \\
\text { sowane }\end{array}$ & $\begin{array}{l}\text { począt- } \\
\text { kujące }\end{array}$ & $\begin{array}{l}\text { pilota- } \\
\text { żowe }\end{array}$ & $\begin{array}{c}\text { brak } \\
\text { działań }\end{array}$ \\
\hline Zbiorowe dostarczanie wody & 83,8 & 15,4 & 0 & 0 & 0,8 \\
\hline $\begin{array}{l}\text { Zbiorowe odprowadzanie i oczyszczanie } \\
\text { ścieków komunalnych }\end{array}$ & 45,2 & 44 & 7,7 & 0 & 3,1 \\
\hline Kanalizacja deszczowa & 14,5 & 47,8 & 20,5 & 2,4 & 14,9 \\
\hline Gospodarka odpadami & 73,7 & 23,9 & 1,9 & 0,4 & 0 \\
\hline Ochrona powietrza & 9,1 & 42,3 & 26,5 & 4,3 & 17,8 \\
\hline Transport, utrzymanie dróg gminnych & 40,6 & 53,8 & 4 & 0,4 & 1,2 \\
\hline Ochrona i utrzymanie terenów zieleni & 25,5 & 53,3 & 10,8 & 2,7 & 7,7 \\
\hline Budownictwo ekologiczne & 1,2 & 13,5 & 35,3 & 8,7 & 41,3 \\
\hline $\begin{array}{l}\text { Ochrona gleb, rekultywacja i rewitalizacja } \\
\text { terenów poprzemysłowych }\end{array}$ & 3,5 & 22,4 & 20 & 3,5 & 50,6 \\
\hline Zabezpieczenie przeciwpowodziowe & 12,4 & 36,3 & 12,7 & 6 & 32,7 \\
\hline Edukacja ekologiczna & 18,4 & 51 & 20,4 & 4,3 & 5,9 \\
\hline $\begin{array}{l}\text { Zmiany sposobu ogrzewania } \\
\text { na proekologiczny i/lub termomodernizacja }\end{array}$ & 13,6 & 45 & 25,2 & 6,6 & 9,7 \\
\hline Alternatywne źródła energii & 4,3 & 19,5 & 46,7 & 12,5 & 17,1 \\
\hline Poprawa efektywności energetycznej & 4,8 & 28,2 & 41,3 & 9,9 & 15,9 \\
\hline Ochrona przyrody i bioróżnorodności & 9,3 & 31,5 & 27,2 & 10,9 & 21 \\
\hline Ochrona przed hałasem & 2,4 & 19,4 & 20,9 & 5,9 & 51,4 \\
\hline
\end{tabular}

Uwaga: kolorem szarym zaznaczono pola z najwyższym udziałem procentowym wśród wszystkich ważnych odpowiedzi.

Źródło: opracowanie własne na podstawie wyników badań ankietowych.

Przedstawiciele gmin we wszystkich badanych województwach za priorytetowe lub bardzo ważne uznali zagadnienia zbiorowego dostarczania wody $(82,8 \%)$ i odprowadzania ścieków $(80,3 \%)$, następnie transport z utrzymaniem dróg gminnych $(76,8 \%)$ i wreszcie gospodarkę odpadami $(59,4 \%)$. Jak wynika z analizy tabeli 2, we wskazanych jako priorytetowe dziedzinach gminy prowadzą bardzo zaawansowane działania $\mathrm{w}$ ramach planowanej polityki sektorowej lub poziom 
ich zaawansowania określany jest jako średnio zaawansowany. Tylko w kwestii budownictwa ekologicznego, ochrony gleb i rekultywacji terenów poprzemysłowych, a także ochrony przed hałasem większość ankietowanych nie prowadzi żadnych działań.

Zasadniczo część problemów stojących przed gospodarką regionalną i lokalną ma charakter długofalowy, co powoduje, że nie można liczyć na to, że rozwiążą się same, zwłaszcza w kontekście specyfiki określonego układu terytorialnego. Dlatego też konieczne staje się inicjowanie i wspieranie przez władze lokalne przedsięwzięć zgodnych z preferencjami i wartościami władz lokalnych oraz perspektywicznymi zamierzeniami rozwojowymi.

Jak wynika z przeprowadzonych badań, większość gmin boryka się z problemem zanieczyszczenia powietrza związanym z występowaniem na badanych obszarach niskiej emisji. W skali całego kraju problem zanieczyszczenia dotyczy głównie groźnego dla zdrowia stężenia pyłu zawieszonego PM10, drobniejszego pyłu PM2,5 oraz benzo(a)pirenu, których normy przekraczane są w wielu miejscowościach przez ponad 100 dni w roku. Źródłem zanieczyszczeń są głównie lokalne kotłownie węglowe i domowe piece, a także emisja komunikacyjna i przemysłowa. W wielu przypadkach w domach palone są śmieci, a wykorzystywane do ogrzewania piece nie spełniają standardów emisyjnych. Obecnie władze samorządowe w ramach działań nastawionych na redukcję zanieczyszczeń powietrza mają możliwość określania, jakie paliwa stałe mogą być wykorzystywane na danym terenie, a przede wszystkim w jakiego rodzaju kotłach mogą być spalane. Priorytetem jest likwidacja kotłów węglowych i zastępowanie ich proekologicznymi źródłami energii, a także wprowadzanie rozwiązań komunikacyjnych, które doprowadzą do obniżenia tzw. emisji liniowej. Ponadto samorządy gminne w ramach prowadzenia programów ograniczania niskiej emisji (PONE) mogą dofinansowywać inwestycje mieszkańców dotyczące likwidacji starych kotłów węglowych oraz zastępowania ich podłączeniem do sieci ciepłowniczej, ogrzewaniem gazowym, olejowym lub elektrycznym albo wykorzystania alternatywnych sposobów pozyskiwania energii w postaci pomp ciepła czy kolektorów słonecznych, które stanowiłyby uzupełniające źródła pozyskiwania energii cieplnej. Mieszkańcy gmin mogą również otrzymać wsparcie finansowe na ten cel z narodowego oraz wojewódzkich funduszy ochrony środowiska i gospodarki wodnej, np. z programu KAWKA. Istotne jest również przeprowadzenie modernizacji gminnej sieci ciepłowniczej, inwestowanie w termomodernizacje budynków oraz unowocześnienie transportu publicznego.

Działania edukacyjne i informacyjne gmin mają fundamentalne znaczenie dla podnoszenia poziomu świadomości ekologicznej mieszkańców, co przekłada się na ograniczenie zanieczyszczeń powietrza i redukcję źródeł niskiej emisji. Pionierem w tych działaniach okazały się władze Krakowa, które jako pierwsze 
w kraju wprowadziły dodatkowy system informowania o zagrożeniu zanieczyszczenia powietrza od poziomu stężenia pyłów przekraczającego $150 \mu \mathrm{g} / \mathrm{m}^{3}$ (według rozporządzenia ministra środowiska obowiązek informowania społeczeństwa rozpoczyna się od poziomu $200 \mu \mathrm{g} / \mathrm{m}^{3}$ ) [Krawczyk 2016]. Dodatkowo władze miasta zapowiadają zamontowanie nowych stacji pomiaru zanieczyszczeń. Działania edukacyjne prowadzą również Katowice, które jako pierwsze miasto w Polsce opracowały i uchwaliły plan gospodarki niskoemisyjnej (narzędzie planistyczne, które gminy powinny posiadać, jeśli chcą ubiegać się o pozyskanie środków z UE w nowej perspektywie finansowej). Prowadzone w jego ramach działania obejmują: planowanie, inwestycje, współpracę, edukację i kontrolę. W latach 2007-2014 miasto przeznaczyło prawie 139 mln zł na termomodernizację budynków użyteczności publicznej, powołało w strukturze Urzędu Miasta Referat Zarządzania Energią, a dla mieszkańców przygotowano portal informacyjno-edukacyjny [Krawczyk 2016].

\section{3. Źródła finansowania inwestycji sektora publicznego oraz główne bariery realizacji idei zrównoważonego rozwoju w gminach}

Współczesne samorządy stoją wobec wyzwań i decyzji związanych z koniecznością określenia dalszej, spójnej wizji swojego rozwoju, nieustannej troski o pozyskanie wystarczającej ilości środków finansowych na realizację określonych w ustawach zadań, jak i własnych projektów inwestycyjnych, które będą determinowały dalszy ich rozwój. Z punktu widzenia konkurencyjności lokalnej i regionalnej wyodrębnia się obszary oddziaływania, które z uwagi na swoją znaczącą rolę w budowaniu atrakcyjności inwestycyjnej danej przestrzeni terytorialnej stanowią przedmiot szczególnego zainteresowania władz lokalnych.

W przeprowadzonych badaniach zapytano władze samorządowe o poziom zaawansowania realizowanych zadań inwestycyjnych w gminie i główne źródła ich finansowania. Odpowiedzi wskazują na braki zarówno w planowaniu, jak i w realizacji w najbliżej przyszłości inwestycji w sektorze komunalnych usług publicznych. Tylko 52\% badanych gmin zrealizowało inwestycje w zakresie zbiorowego dostarczania wody, a inwestycje dotyczące poprawy efektywności energetycznej i odnawialnych źródeł energii planuje ponad 50\% badanych gmin. Transport zbiorowy, utrzymanie dróg gminnych oraz odprowadzanie i oczyszczanie ścieków komunalnych to jedyne obszary, w których większość przedstawicieli gmin deklarowała inwestycje w trakcie realizacji, natomiast w pozostałych wyszczególnionych w ankiecie obszarach zdecydowana większość gmin nie realizuje inwestycji i nie uwzględnia ich w planach rozwoju. Inwestycje komunalne, 
zwłaszcza te infrastrukturalne, odgrywają znaczącą rolę w kreowaniu rozwoju gospodarczego i stymulowaniu innych, już nie przez gminę prowadzonych inwestycji. Polityka inwestycyjna gmin powinna zatem opierać się na świadomym i celowym wyborze przedsięwzięć inwestycyjnych według ustalonych kryteriów oraz na odpowiednim doborze źródeł ich finansowania.

Badane gminy wskazały środki własne jako dominujące źródło finansowania prawie wszystkich rodzajów usług komunalnych i środowiskowych. Z analizy tabeli 3 wynika, że ich udział wynosi od $25,6 \% \mathrm{w}$ przypadku ochrony przed hałasem do 83,8\% w sektorze transportu. Obszarami, w których dominowały wskazania na źródła zewnętrzne finansowania inwestycji, w postaci funduszy unijnych, były: gospodarka wodno-ściekowa, gospodarka energetyczna oraz budownictwo ekologiczne. Można również zaobserwować marginalne znaczenie środków komercyjnych oraz formuły partnerstwa publiczno-prywatnego w finansowaniu tego typu inwestycji.

Wiele regionów, gmin i miast zmaga się z problemem niedoinwestowania w zakresie infrastruktury transportowej. Istotnym problemem jest również niska dostępność komunikacyjna, niedostosowanie sieci drogowej do natężenia ruchu prowadzące do zakłóceń płynności ruchu i stanowiące jeden z czynników ograniczających zrównoważony rozwój. Wyposażenie danego obszaru w obiekty infrastruktury społeczno-gospodarczej, zwłaszcza transportowej, jest jednym z czynników i wyznaczników atrakcyjności inwestycyjnej. W przeprowadzonych badaniach jedynymi obok odprowadzania i oczyszczania ścieków komunalnych inwestycjami wskazanymi przez respondentów, będącymi w trakcie realizacji, są właśnie te związane z transportem i utrzymaniem dróg gminnych - wskazało je $w$ ankiecie aż $65 \%$ gmin. $Z$ jednej strony taki stan rzeczy wynika $\mathrm{z}$ wywiązywania się przez samorząd z obowiązkowych zadań narzuconych ustawowo, a z drugiej inwestycje transportowe (głównie infrastrukturalne) przyczyniają się do zwiększenia atrakcyjności inwestycyjnej regionu i mogą wpływać na wzrost jakości życia mieszkańców.

Przedstawiciele gmin wytypowali również w trakcie badania destymulanty rozwoju, wśród których znalazły się głównie te o charakterze finansowo-ekonomicznym. Prawie $90 \%$ uznało za podstawową barierę ograniczone środki własne gminy, które mogą być przeznaczane na cele związane z ochroną środowiska i zrównoważonym rozwojem, a 75\% respondentów uznało ugruntowane nawyki i zachowania mieszkańców za czynniki niekorzystne w realizacji strategii gmin. Co zadziwiające, pomimo różnic uwarunkowań rozwoju poszczególnych województw wskazania badanych respondentów dotyczące czynników hamujących lokalny zrównoważony rozwój wydają się niemal jednakowe. Według wyników przeprowadzonych badań ankietowych w gminach wszystkich badanych województw dominują bariery prawno-polityczne oraz instytucjonalno-organizacyjne. 
Tabela 3. Główne źródła finansowania inwestycji z podziałem na obszary usług publicznych (\% ważnych odpowiedzi)

\begin{tabular}{|c|c|c|c|c|c|}
\hline Rodzaj/obszar usług & $\begin{array}{l}\text { Środki } \\
\text { własne }\end{array}$ & $\begin{array}{l}\text { NFOŚiGW } \\
\text { lub } \\
\text { WFOŚiGW }\end{array}$ & $\begin{array}{l}\text { Fundusze } \\
\text { UE }\end{array}$ & $\begin{array}{c}\text { Środki } \\
\text { komercyjne }\end{array}$ & $\begin{array}{l}\text { Partnerstwo } \\
\text { publiczno- } \\
\text {-prywatne }\end{array}$ \\
\hline Zbiorowe dostarczanie wody & 70,2 & 31,0 & 38,8 & 5,8 & 0,8 \\
\hline $\begin{array}{l}\text { Zbiorowe odprowadzanie } \\
\text { i oczyszczanie ścieków } \\
\text { komunalnych }\end{array}$ & 67,8 & 56,2 & 68,2 & 8,5 & 1,6 \\
\hline Kanalizacja deszczowa & 58,5 & 24,0 & 32,6 & 3,9 & 0,0 \\
\hline Gospodarka odpadami & 61,2 & 27,1 & 19,0 & 3,1 & 2,3 \\
\hline Ochrona powietrza & 41,5 & 34,5 & 31,8 & 3,1 & 0,4 \\
\hline $\begin{array}{l}\text { Transport, utrzymanie dróg } \\
\text { gminnych }\end{array}$ & 83,8 & 11,6 & 58,5 & 9,3 & 2,7 \\
\hline $\begin{array}{l}\text { Ochrona i utrzymanie terenów } \\
\text { zieleni }\end{array}$ & 63,6 & 16,3 & 19,4 & 2,3 & 0,8 \\
\hline Budownictwo ekologiczne & 20,5 & 14,7 & 27,9 & 3,1 & 2,3 \\
\hline $\begin{array}{l}\text { Ochrona gleb, rekultywacja } \\
\text { i rewitalizacja terenów } \\
\text { poprzemysłowych }\end{array}$ & 26,0 & 13,6 & 21,3 & 2,3 & 0,8 \\
\hline $\begin{array}{l}\text { Zabezpieczenie przeciw- } \\
\text { powodziowe }\end{array}$ & 34,9 & 14,3 & 16,3 & 2,7 & 1,6 \\
\hline Edukacja ekologiczna & 65,1 & 31,0 & 18,2 & 1,2 & 1,6 \\
\hline $\begin{array}{l}\text { Zmiany sposobu ogrzewania/ } \\
\text { termomodernizacja }\end{array}$ & 61,6 & 49,6 & 57,0 & 4,3 & 0,4 \\
\hline Alternatywne źródła energii & 39,5 & 33,3 & 53,1 & 3,9 & 1,2 \\
\hline $\begin{array}{l}\text { Poprawa efektywności } \\
\text { energetycznej }\end{array}$ & 51,6 & 38,0 & 56,2 & 3,5 & 1,6 \\
\hline $\begin{array}{l}\text { Ochrona przyrody i bioróżno- } \\
\text { rodności }\end{array}$ & 36,8 & 22,1 & 22,5 & 2,3 & 0,0 \\
\hline Ochrona przed hałasem & 25,6 & 14,7 & 15,1 & 0,8 & 0,0 \\
\hline
\end{tabular}

Uwaga: kolorem szarym zaznaczono pola z najwyższym udziałem procentowym wśród wszystkich ważnych odpowiedzi.

Źródło: opracowanie własne na podstawie wyników badań ankietowych.

Natomiast w grupie najrzadziej zauważanych przez respondentów barier pojawiły się te, które w większym stopniu dotyczą sfery technicznej niż ekonomiczno-społecznej oraz instytucjonalno-prawnej. Analizując wyniki badań, można również zauważyć, że bezrobocie jest rzadko dostrzeganą przez gminy barierą zrównoważonego rozwoju (ogółem 14\% wskazań), podobnie jak niska inno- 
wacyjność lokalnego przemysłu (20\%) czy też niski poziom przedsiębiorczości (18\%). Problemy związane z brakiem wykształconej kadry w zakresie ochrony środowiska i zrównoważonego rozwoju oraz z występowaniem zjawiska ubóstwa i wykluczenia z korzystania z niektórych usług środowiskowych ze względu na ograniczenia finansowe mieszkańców na poziomie gminnym nie zawsze są dostrzegane (odpowiednio 10\% i 14\% wskazań).

\section{Wnioski}

Pomimo zróżnicowanych uwarunkowań środowiskowo-przyrodniczych i zasobowych, a także charakteru i funkcji badanych regionów uzyskane w badaniach gmin wyniki okazały się zaskakująco zbieżne. Pozwoliło to na sformułowanie następujących wniosków:

1) podstawowym problemem ekologicznym wskazywanym przez respondentów jest niska emisja z domów mieszkalnych, czego konsekwencją jest zły stan powietrza występujący na całym obszarze Polski. Ponadto większość badanych gmin prowadzi działania w dziedzinach określonych przez siebie jako priorytetowe, na poziomie bardzo lub średnio zaawansowanym. Niepokojącym zjawiskiem zaobserwowanym w trakcie badań jest nieprowadzenie przez władze gmin monitoringu jakości usług komunalnych;

2) najczęściej wymienianym źródłem finansowania niezbędnych inwestycji dotyczących analizowanych usług publicznych są środki własne samorządów. Marginalne znaczenie ma finansowanie działań ze źródeł komercyjnych czy w formule partnerstwa publiczno-prywatnego;

3) ograniczone środki finansowe gmin stanowią podstawową barierę wdrażania koncepcji zrównoważonego rozwoju na poziomie lokalnym. Władze gmin identyfikują jednak zdecydowanie więcej korzyści z wdrażania zrównoważonego rozwoju niż barier. Przedstawiciele gmin wszystkich województw wskazywali najczęściej poprawę jakości i warunków życia mieszkańców oraz na poprawę stanu środowiska naturalnego lub poprawę czystości i jakości powietrza jako zarówno osiągane korzyści, jak i stymulanty rozwoju. Ponadto w grupie czynników określonych przez respondentów jako szanse rozwojowe znalazły się czynniki związane z infrastrukturą i poprawą atrakcyjności inwestycyjnej gminy.

\section{Literatura}

Borys T. [2011], Zrównoważony rozwój - jak rozpoznać ład zintegrowany, „Problemy Ekorozwoju", vol. 6, nr 2.

Fiedor B., Jończy R. [2009], Globalne problemy interpretacji i wdrażania koncepcji sustainable development [w:] Rozwój zrównoważony. Teoria i praktyka ze szcze- 
gólnym uwzględnieniem obszarów wiejskich, red. B. Fiedor, R. Jończy, Uniwersytet Ekonomiczny we Wrocławiu, Wrocław.

Flejtarski S., Panasiuk A., Perenc J., Rosa G. [2012], Współczesna ekonomika usług, PWN, Warszawa.

Kożuch B., Kożuch A. [2011], Usługi publiczne. Organizacja i zarządzanie, Uniwersytet Jagielloński, Kraków.

Krawczyk B. [2016] Jak samorzady ograniczają niska emisję?, „Przegląd Komunalny”, nr 2.

Perło D. [2013], Modelowanie „zielonej gospodarki” województwa podlaskiego jako narzędzie zarządzania zrównoważonym rozwojem regionu, „Zarządzanie i Finanse”, nr 3.

Stiglitz J.E. [2014], Ekonomia sektora publicznego, PWN, Warszawa.

Strategia rozwoju województwa podlaskiego do roku 2020 [2013], Urząd Marszałkowski Województwa Podlaskiego, Białystok.

Strategia rozwoju województwa śląskiego „Śląskie 2020+” [2013], Urząd Marszałkowski Województwa Śląskiego, Katowice.

Szarfenberg R. [2009], Standaryzacja usług społecznych, Centrum Rozwoju Zasobów Ludzkich, Warszawa.

Wańkowicz W. [2004], Wskaźniki realizacji usług publicznych, MSAP, Kraków.

Wielkopolska 2020. Zaktualizowana strategia rozwoju województwa wielkopolskiego do roku 2020 [2012], Zarząd Województwa Wielkopolskiego, Poznań.

\section{Public Services in Municipalities Sustainable Development Policy - Selected Issues}

(Abstract)

The aim of this study is to identify the main barriers municipalities face and the benefits they gain from implementing sustainable development from authorities point of view. The paper also presents the main directions and activities public authorities have implemented in technical and environmental public services. It also discusses the results of empirical research conducted in 2015 in municipalities in the voivodeships of Wielkopolska, Silesia and Podlasie. The main conclusion of the research is that effectively implementing sustainable development policy largely depends on the awareness and involvement of local authorities. The paper shows that in many municipalities, economic, social and environmental development factors aren't balanced. Moreover, sustainable development programming and activity should improve the quality of life for inhabitants, but they often fail to leave the planning stage.

Keywords: sustainable development, public services, municipality, Poland. 